DOI: https://doi.org/10.32366/2523-4269-2021-77-4-143-148
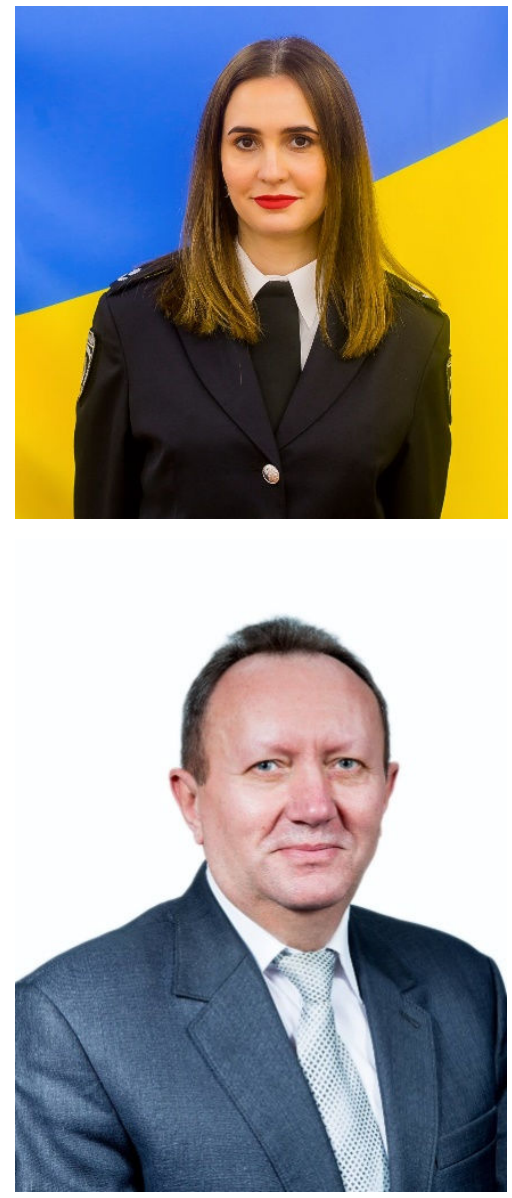

Бабенко Ольга Георгївна,

доктор філософії за спеціальністю «Право»

(Донеиький держсвний університет

внутрішніх справ, м. Кривий Ріг)

ORCID: https://orcid.org/0000-0003-4218-2191

Репан Микола Іванович

(Дніпропетровський державний

університет внутрішніх справ, м. Дніпро)

ORCID: https://orcid.org/0000-0001-9251-0961

\section{АНАЛІЗ ПОЛОЖЕНЬ ПРОЕКТУ ЗАКОНУ УКРАЇНИ «ПРО ЗАБЕЗПЕЧЕННЯ БЕЗПЕКИ УЧАСНИКІВ КРИМІНАЛЬНОГО СУДОЧИНСТВА ТА ІНШИХ ОСІБ В ІНТЕРЕСАХ ПРАВОСУДДЯ»}

Статтю присвячено аналізу проєкту Закону України «Про забезпечення безпеки учасників кримінального судочинства та інших осіб в інтересах правосуддя». Установлено, шзо чинне законодавство у сфері забезпечення захисту учасників кримінального судочинства $\epsilon$ не реформованим і таким, щуо втратило ефективність. Констатовано, щео учасники кримінального судочинства іноді приховують дійсні дані вчинення злочину, тому щчо побоюються за своє життя та здоров'я у разі надання викривальних показань, оскільки інститут забезпечення безпеки учасників кримінального судочинства нині не є дієвим. Виявлено, щзо Проєкт не передбачає особливостей забезпечення безпеки неповнолітніх учасників кримінального провадження, щзо суттєво порушує права иієї вразливої категорї осіб. Зроблено висновок, щуо законопроєкт потребує вдосконалення та максимального збільшення ефективності та дієвості його норм.

Ключові слова: проєкт; забезпечення безпеки; учасники кримінального судочинства; неповнолітні; законні представники.

Постановка проблеми. Потрапляючи до сфери кримінального судочинства, особа набуває певного процесуального статусу, згідно з яким у неї виникають певні права й обов'язки, передбачені Кримінальним процесуальним кодексом України. Серед значного переліку процесуальних прав учасники кримінального провадження мають право на забезпечення безпеки щодо себе, близьких родичів чи членів своєї сім'ї, майна та житла, за наявності відповідних підстав.

Нормативно-правовим актом, який встановлює підстави, умови й порядок застосування заходів забезпечення безпеки учасників кримінального судочинства є Закон 
України «Про забезпечення безпеки осіб, які беруть участь у кримінальному судочинстві», прийнятий 23.12.1993 р. (далі - Закон) [1].

Прагнення держави до вступу в Європейський Союз вимагає від законотворця вдосконалювати свої напрацювання і надавати їм більш новітнього й актуального стану, ураховуючи міжнародно-правові акти.

У зв’язку з цим народним депутатом України Денисом Монастирським у порядку законодавчої ініціативи було внесено на розгляд Верховної Ради України проєкт Закону України «Про забезпечення безпеки учасників кримінального судочинства та інших осіб в інтересах правосуддя» (далі - Проєкт). У пояснювальній записці до Проєкту зазначено, що на сьогодні система забезпечення безпеки осіб, які беруть участь у кримінальному судочинстві, є застарілою і не забезпечує необхідних умов для належного відправлення правосуддя [2], з чим, безсумнівно, варто погодитися.

Аналіз останніх досліджень і публікацій. Окремими питаннями вдосконалення інституту забезпечення безпеки учасників кримінального судочинства в різний час займалися такі вчені, як В. П. Бахін, В. К. Весельський, В.І.Галаган, Ю. В. Гуцуляк, В. С. Зеленецький, С. Д. Лук'янчиков, М. В. Новикова, А. М. Орлеан, М. А. Погорецький, С. М. Стахівський, В. М. Тертишник та ін. Проте, незважаючи на велику кількість наукових праць у цій сфері, законодавство щодо забезпечення безпеки учасників кримінального судочинства є неефективним та потребує кардинальних змін.

Формування цілей статті (постановка завдання). Метою статті $є$ аналіз запропонованого проєкту Закону України «Про забезпечення безпеки учасників кримінального судочинства та інших осіб в інтересах правосуддя», його узагальнення, визначення недоліків і винайдення шляхів удосконалення для більш ефективного його застосування.

Виклад основного матеріалу. У проєкті Закону України «Про забезпечення безпеки учасників кримінального судочинства та інших осіб в інтересах правосуддя» зазначено його ціль - удосконалення наявної системи забезпечення безпеки учасників кримінального судочинства й інших осіб в інтересах правосуддя в Україні та узгодження іiі 3 міжнародними стандартами й зарубіжними практиками в цій сфері правовідносин.

Чинний Закон навіть після внесення до нього численних змін і доповнень все ж не дає змоги оптимізувати правові, організаційні та технічні заходи під час організації та здійсненні заходів безпеки i позбавити органи, що здійснюють заходи безпеки, невластивих їм функцій [3].

Основною метою Проєкту є встановлення довіри сумлінних громадян до системи забезпечення безпеки під час кримінального судочинства; збільшення ефективності розкриття злочинів та забезпечення належного відправлення правосуддя у кримінальних провадженнях, участь у яких беруть особливо важливі свідки чи інші учасники судочинства. Захист прав осіб-учасників та дотримання їх особистої безпеки зумовлює законодавця вдосконалювати свої напрацювання, беручи приклад 3 успішних країн Європи.

Можна погодитися 3 думкою, висловленою в пояснювальній записці до Проєкту, що чинне законодавство не відповідає вимогам сучасності. Слід звернути увагу на рекомендації Комітету міністрів Ради Європи (наприклад, Rec (97) 13 та Rec (2005) 9), що містять принципи, якими необхідно керуватися під час захисту свідків. Належне їх упровадження на національному рівні $\epsilon$ гарантією поєднання ефективного та справедливого судочинства 3 одночасним убезпеченням свідків та потерпілих від незаконного впливу. Однією 3 вимог згаданих рекомендацій щодо захисту свідків i потерпілих $є$ створення окремих органів (структур), що повинні мати оперативну автономію і не брати участі в підготовці справи чи розслідуванні (п. 28 Рекомендацій Rес (2005) 9) [3]. 
Правовий часопис Аонбасу № 4 (77) 2021

Позитивним є запропоноване в Проєкті створення нового спеціально уповноваженого органу - Національного агентства 3 питань забезпечення безпеки учасників кримінального судочинства, оскільки у разі виникнення високого рівня загрози певним учасникам кримінального провадження їх права та свободи, життя і здоров'я повинно бути збережено.

Наприклад, у Сполучених Штатах Америки в рамках програми WITSEC відповідні заходи покладені на Службу судових приставів, у Німеччині цим займається спеціальний підрозділ кримінальної поліції. В Австрії, Словаччині та Великобританії захист свідків забезпечується поліцією, у Нідерландах програма діє в межах виконавчої та судової влади [3].

Створення окремого органу із забезпечення безпеки людей стане досить ефективним, адже його діяльність буде направленою виключно на захист учасників кримінального процесу та не відволікатиме його працівників на дотримання строків розслідування, збирання доказів тощо.

У ч. 2 ст. 2 Проєкту вказано, що «при прийнятті рішення про застосування заходів забезпечення безпеки в обов'язковому порядку має враховуватися тяжкість злочину, значущість внеску відповідного учасника кримінального судочинства у належне відправлення правосуддя та характер і ступінь загрози». Варто зазначити, що, зважаючи на лише перелічені критерії для прийняття рішення щодо застосування заходів забезпечення безпеки, законотворець не звернув уваги на особистість суб'єкта вчинення злочину. Оскільки загроза життю та здоров'ю учасникам кримінального судочинства (наприклад, свідкам, потерпілим) може надходити безпосередньо від особи, яка вчинила злочин, потрібно враховувати саме цей параметр оцінювання небезпечності.

Отже, пропонуємо частину 2 статті 2 Проєкту викласти в такій редакції: «Під час прийняття рішення про застосування заходів забезпечення безпеки в обов'язковому порядку має враховуватися тяжкість злочину, особистість суб'єкта вчинення злочину, значущість внеску відповідного учасника кримінального судочинства в належне відправлення правосуддя та характер і ступінь загрози».

У розділі 2 «Особи, які підлягають захисту, та особи, взяті під захист, органи, що уповноважені забезпечувати безпеку, їх права та обов'язки» Проєкту надано перелік осіб, які мають право на застосування заходів забезпечення безпеки. Однак у Проєкті не звернено увагу на таку специфічну категорію осіб, як неповнолітні. Оскільки міжнародна спільнота спрямована на забезпечення додатковими гарантіями захисту прав і свобод та намагається дотримуватися міжнародних стандартів у цій сфері, варто наголосити на концепції забезпечення «найкращих інтересів дитини».

Так, у Декларації прав дитини, прийнятій 20 листопада 1959 року Генеральною Асамблеєю Організації Об’єднаних Націй, закріплено принцип якнайкращого забезпечення інтересів дитини та враховано, що дитина внаслідок її фізичної і розумової незрілості потребує спеціальної охорони й піклування, зокрема належного правового захисту до й після народження [4].

Зважаючи на перелік осіб, що мають право на застосування заходів забезпечення безпеки, запропонований у ч. 1 ст. 6 Проєкту, можна розуміти, що нормотворець передбачив можливість взяття під захист неповнолітнього в тому чи іншому статусі [5], але, на жаль, залишив поза увагою їх батьків та законних представників.

Аналізуючи пункти 1 та 2 статті 3 Конвенції про права дитини, потрібно зауважити, що в усіх діях щодо дітей, незалежно від того, чи здійснюються вони державними або приватними установами, що займаються питаннями соціального забезпечення, судами, адміністративними чи законодавчими органами, приділено увагу насамперед якнайкращому забезпеченню інтересів дитини. Зокрема, дитині має бути надано такий захист і піклування, які необхідні для іiі благополуччя, зважаючи на права й обов'язки іiі батьків, опікунів чи інших осіб, які відповідають за неї за законом, із цією метою вживають всіх відповідних законодавчих й адміністративних заходів [6]. 
3 огляду на зазначене та враховуючи концепцію «найкращих інтересів дитини», убачаємо доцільним розширити перелік осіб, які підлягають захисту, та доповнити ч. 1 ст. 6 Проєкту таким змістом: «8) законний представник неповнолітньої, недієздатної чи обмежено дієздатної особи».

Розглядаючи статтю 4 Проєкту, варто акцентувати на запропонованих правах осіб, узятих під захист. Указаний перелік прав стосується більшою мірою лише їх реалізації під час застосування Закону. Навіть зазначене в п. 6 цієї статті «звертатися із заявою про застосування заходів соціально-правового характеру» [5] є не категоричним правом, тобто дитина або «має право звернутися із заявою», або може не скористатися таким правом 3 тих чи інших обставин.

Комітет $\mathrm{OOH}$ із прав дитини принцип «найкращих інтересів дитини» роз'яснює в Зауваженні загального порядку № 14 (2013) «Про право дитини на приділення першочергової уваги якнайкращому забезпеченню ії інтересів» [7].

Інтереси дитини в контексті Проєкту, крім запропонованих прав, варто розуміти як:

- роботу 3 психологом (оскільки безпосередня участь у кримінальному судочинстві та застосування Закону вже $є$ стресом для такої вразливої категорії, як неповнолітні);

- д дистанційну або очну освіту (право, гарантоване не лише Конституцією України, а й багатьма іншими міжнародно-правовими актами);

забезпечення перебування неповнолітнього під захистом у найбільш звичних для нього умовах, оскільки будь-яка серйозна зміна навколишньої обстановки та середовища є психологічно важкою для неповнолітніх.

3 огляду на це пропонуємо доповнити статтю 4 Проєкту таким змістом: «8) на інші додаткові гарантії захисту прав, якщо особа, що береться під захист, не досягла повноліття, зокрема роботу 3 психологом, дистанційну освіту, забезпечення перебування неповнолітнього під захистом у найбільш звичних для них умов».

Відповідно до пункту 3 статті 10 Проєкту одним із спеціальних заходів забезпечення безпеки є «забезпечення фізичної безпеки особи» [5].

У контексті Проєкту поняття «забезпечення фізичної безпеки особи» стосується і неповнолітнього. 3 урахуванням концепції забезпечення «найкращих інтересів дитини» варто доповнити пункт 3 статті 10 Проєкту словами «у тому числі законного представника неповнолітнього, недієздатної чи обмежено дієздатної особи». Оскільки законні представники неповнолітнього майже постійно повинні перебувати поруч з дітьми, які без них $є$ вразливими та незахищеними, слід брати під захист і їх. Зважаючи на те, що насамперед батьки несуть відповідальність за безпеку та життя своїх дітей, пропозиція забезпечувати фізичною безпекою саме законних представників неповнолітнього $\epsilon$ актуальною та такою, що наділяє цю специфічну категорію осіб додатковими гарантіями захисту прав.

Таке ж саме обгрунтування можна застосувати до пункту 6 статті 10 Проєкту. 3 огляду на те, що переселення неповнолітнього, якого взято під захист, без законного представника буде психічно важким, тому необхідно дотриматися принципу «найкращих інтересів дитини» та не розлучати дітей із батьками.

У пункті 7 статті 10 Проєкту зазначено, що спеціальним заходом забезпечення безпеки є зміна зовнішності [5].

Не оминаючи участі в кримінальному судочинстві такої специфічної категорії, як неповнолітні, варто зауважити, що цей захід безпеки не повинен застосовуватися до осіб, які не досягли 16-річного віку, адже неповнолітні через несформовану психіку, відсутність життєвого досвіду без допомоги посередників не можуть правильно розуміти всіх правових наслідків того, що відбувається під час кримінального судочинства. Тому запропонований законотворцем захід безпеки «зміна зовнішності» не припустимий для такої специфічної категорії, як неповнолітні. 
Тож пропонуємо пункт 7 статті 10 Проєкту викласти в такій редакції: «7) зміна зовнішності, окрім осіб, які не досягли віку 16 років».

На цій підставі варто внести забороняючу норму до статті 17 Проєкту та додати абзац другий такого змісту: «Зміна зовнішності забороняється щодо осіб, які не досягли віку 16 років».

Висновки. За результатами розгляду та аналізу проєкту Закону України «Про забезпечення безпеки учасників кримінального судочинства та інших осіб в інтересах правосуддя» можна зробити висновок, що законотворець намагається рівнятися на сучасні та цивілізовані країни Свропи. Однак ментальність українського народу дещо інша, ніж у Європі, тому наші громадяни, які стали учасниками кримінального процесу, щодо яких виникає необхідність забезпечення їх безпеки, потребують не лише додаткового захисту, а й ефективної процедури його реалізації. Проєкт однозначно вимагає вдосконалення певних норм, особливо щодо забезпечення безпеки дітей, які стали учасниками кримінального судочинства. Запропоновані нами зміни та доповнення до досліджуваного Проєкту стануть підгрунтям для дотримання прав людини, зокрема неповнолітніх, та наближення національного законодавства до європейського рівня.

Перспективами подальших розвідок у цьому напрямі визначено дослідження шляхів підвищення ефективності законодавства, що регулює забезпечення безпеки учасників кримінального судочинства.

\section{Список використаних джерел}

1. Про забезпечення безпеки осіб, які беруть участь у кримінальному судочинстві : Закон України від 23.12.1993. URL: https://zakon.rada.gov.ua/laws/show/3782-12\#Text (дата звернення: 07.10.2021).

2. Пояснювальна записка до проєкту Закону України «Про забезпечення безпеки учасників кримінального судочинства та інших осіб в інтересах правосуддя»/ Монастирський Д. та ін. URL: http://w1.c1.rada.gov.ua/pls/zweb2/webproc4_1?pf3511=72472 (дата звернення: 07.10.2021).

3. Висновок на проєкт Закону України № 5751 від 12.07.2021 «Про забезпечення безпеки осіб, які беруть участь у кримінальному судочинстві». URL: https://ips.ligazakon.net/document/view/XH6IX00A?an=3 (дата звернення: 07.10.2021).
4. Декларація
прав
дитини
від
20.11.1959.
URL:

https://zakon.rada.gov.ua/laws/show/995_384\#Text (дата звернення: 07.10.2021).

5. Проєкт Закону України «Про забезпечення безпеки осіб, які беруть участь у кримінальному судочинстві» № 5751 від 12.07.2021. URL: http://w1.c1.rada.gov.ua/pls/zweb2/webproc4_1?pf3511=72472 (дата звернення: 07.10.2021).

6. Конвенція про права дитини від 20 листопада 1989 року. URL: https://zakon.rada.gov.ua/laws/show/995_021\#Text (дата звернення: 07.10.2021).

7. Комитет по правам ребенка. Замечание общего порядка № 14 (2013) о праве ребенка на уделение первоочередного внимания наилучшему обеспечению его интересов (пункт 1 статьи 3). 29 May 2013. URL:

http://docstore.ohchr.org/SelfServices/FilesHandler.ashx?enc=6QkG1d\%2FPPRiCAqhKb7yhsqIkirKQZLK2M 58RF\%2F5F0vEAXPu5AtSWvliDPBvwUDNU\%2BXzNo\%2BP87FA3t6o0hLTWqi3zDRy4oCA3DO7\%2FT HxE70da0GupUJShCbh9\%2FH1atuIz (дата звернення: 07.10.2021).

\section{References}

1. Pro zabezpechennia bezpeky osib, yaki berut uchast u kryminalnomu sudochynstvi [On ensuring the safety of persons involved in criminal proceedings]: Zakon Ukrainy vid 23.12.1993. URL: https://zakon.rada.gov.ua/laws/show/3782-12\#Text (data zvernennia: 07.10.2021) [in Ukrainian].

2. Poiasniuvalna zapyska do proiektu Zakonu Ukrainy «Pro zabezpechennia bezpeky uchasnykiv kryminalnoho sudochynstva ta inshykh osib $\mathrm{v}$ interesakh pravosuddia» [Explanatory note to the draft Law of Ukraine "On ensuring the safety of participants in criminal proceedings and other persons in the interests of justice"] / Monastyrskyi D. ta in. URL: http://w1.c1.rada.gov.ua/pls/zweb2/webproc4_1?pf3511=72472 (data zvernennia: 07.10.2021) [in Ukrainian]

3. Vysnovok na proekt Zakonu Ukrainy № 5751 vid 12.07.2021 "Pro zabezpechennia bezpeky osib, yaki berut uchast u kryminalnomu sudochynstvi" [Opinion on the draft Law of Ukraine № 5751 of 12.07.2021 
"On ensuring the safety of persons involved in criminal proceedings"]. URL: https://ips.ligazakon.net/document/view/XH6IX00A?an=3 (data zvernennia: 07.10.2021) [in Ukrainian].

4. Deklaratsiia prav dytyny vid 20.11.1959 [Declaration of the Rights of the Child dated November 20, 1959]. URL: https://zakon.rada.gov.ua/laws/show/995_384\#Text (data zvernennia: 07.10.2021) [in Ukrainian].

5. Proekt Zakonu Ukrainy "Pro zabezpechennia bezpeky osib, yaki berut uchast u kryminalnomu sudochynstvi" № 5751 vid 12.07.2021 [Draft Law of Ukraine "On Ensuring the Security of Persons Participating in Criminal Proceedings" № 5751 of July 12, 2021]. URL: http://w1.c1.rada.gov.ua/pls/zweb2/webproc4_1?pf3511=72472 (data zvernennia: 07.10.2021) [in Ukrainian].

6. Konventsiia pro prava dytyny vid 20 lystopada 1989 roku [Convention on the Rights of the Child of 20 November 1989]. URL: https://zakon.rada.gov.ua/laws/show/995_021\#Text (data zvernennia: 07.10.2021) [in Ukrainian].

7. Komitet po pravam rebenka. Zamechanie obshchego poryadka № 14 (2013) o prave rebenka na udelenie pervoocherednogo vnimaniya nailuchshemu obespecheniyu ego interesov (punkt 1 stat'i 3). 29 May 2013 [Committee on the Rights of the Child. General comment No. 14 (2013) on the child's right to the best interests of the child (art. 3, paragraph 1). May 29, 2013]. URL: http://docstore.ohchr.org/SelfServices/FilesHandler.ashx?enc=6QkG1d\%2FPPRiCAqhKb7yhsqIkirKQZLK2M 58RF\%2F5F0vEAXPu5AtSWvliDPBvwUDNU\%2BXzNo\%2BP87FA3t6o0hLTWqi3zDRy4oCA3DO7\%2FT HxE70da0GupUJShCbh9\%2FH1atuIz (data zvernennia: 07.10.2021) [in Russian].

Babenko Olha,

Doctor of Philosophy in Law

(Donetsk State University of Internal Affairs, Kryvyi Rih)

ORCID: https://orcid.org/0000-0003-4218-2191

Repan Mykola

(Dnipropetrovsk State University of Internal Affairs, Dnipro)

ORCID: https://orcid.org/0000-0001-9251-0961

\title{
ANALYSIS OF THE PROVISIONS OF THE DRAFT LAW OF UKRAINE "ON ENSURING THE SECURITY OF PARTICIPANTS IN CRIMINAL JUDICIARY AND OTHER PERSONS IN THE INTEREST OF JUSTICE"
}

\begin{abstract}
The article is devoted to the analysis of the Draft Law "On Ensuring the Safety of Participants in Criminal Proceedings and Other Persons in the Interests of Justice". The system of current legislation in the field of security of persons involved in criminal proceedings is outdated and does not provide the necessary conditions for the proper administration of justice. It is established that the current legislation in the field of protection of participants in criminal proceedings is unreformed, has many gaps and is ineffective. It was stated that participants in criminal proceedings (witnesses and victims) who are in real danger often refuse to testify and cooperate with the investigator, as they believe that the state cannot protect them from the unlawful influence of persons involved in criminal proceedings. As a result of the refusal of witnesses and victims to testify and cooperate with the investigation, the perpetrators remain unpunished. On the positive side of the draft law is the proposal to establish a new specially authorized body - the National Agency for Security of Criminal Proceedings, as in the event of a high level of threat to certain participants in criminal proceedings, their rights and freedoms, life and health must be preserved. It was found that the Draft Law does not provide for the specifics of ensuring the safety of juvenile participants in criminal proceedings, which significantly violates the rights of this vulnerable category of persons. Based on the understanding of the list of persons entitled to the application of security measures proposed in Part 1 of Art. 6 of the draft Law, it can be understood that the legislator provided for the possibility of taking under the protection of a minor, in one form or another, but unfortunately bypassed the attention of their parents and legal representatives. In view of the above and taking into account the concept of "best interests of the child", it is proposed to expand the list of persons subject to protection and add a legal representative of a minor. There have also been a number of other proposals to improve the situation of juveniles who are being protected by the state for giving incriminating testimony. It is concluded that the bill needs to improve and maximize its efficiency and effectiveness of its rules.
\end{abstract}

Key words: Draft; security; participants of criminal proceedings; minors; legal representatives. 